\title{
Industrialized Wall Components Impacts on Cooling Load Reduction and Carbon Production
}

\author{
Mahmoud Shakouri Hassanabadi and Seyed Saeed Banihashemi
}

\begin{abstract}
Green building has now become a flagship of sustainable development in Malaysia that takes the responsibility for balancing long-term economic, environmental and social health. High total load green house gas emissions and inefficient energy consumption are the issues that the building sector in Malaysia is struggling with. To cope with these issues, Malaysian construction industry has been urged to use more innovative construction techniques like industrialized building system and building information modeling. This paper aims at evaluating the efficiency of various types of prefabricated wall components with regard to resource consumption and environmental impact and consequently, draws an analogy between them and the conventional types. The case study in this paper is a double storey bungalow located in Kuala Lumpur. It was modeled in Revit Architecture and exported to Autodesk Ecotect Analysis for energy simulation. Results show that the selected prefabricated walls, in terms of reducing the cooling loads, perform better than the conventional walls but this reduction is not significant. In general, this conclusion is drawn that IBS technology doesn't play a conspicuous role in energy efficiency. However, its contribution to promote sustainability may fall in other categories.
\end{abstract}

Index Terms-IBS, cooling load, carbon production, wall panels, green building

\section{INTRODUCTION}

Industrial sectors, including the building sector, started to recognize the impact of their activities on the environment in the 1990s. Significant changes were needed to mitigate the environmental impacts of building sector. The building sector had to focus on how buildings were designed, built and operated [1]. Green building has now become a flagship of sustainable development in Malaysia that takes the responsibility for balancing long-term economic, environmental and social health [2]. The Malaysian green building index (GBI) has been developed recently by association of consulting engineers Malaysia (ACEM) and pertubuhan arkitek Malaysia (PAM) and it offers an opportunity to create environmentally efficient buildings by using an integrated approach of design so that the negative impacts of building on the environment and occupants are reduced. The concept of sustainable development can be traced to the energy (especially fossil oil) crisis and the environment pollution concern in the 1970s [3].

Energy consumption is the main cause for greenhouse gas emissions worldwide. It is estimated that the construction

Manuscript received November 17, 2011; revised December 26, 2011.

Authors are with the Department of Construction Management, Faculty of Civil Engineering, University Teknologi Malaysia, (e-mail: shmahmoud3@live.utm.my; shmahmoud3@live.utm.my). sector accounts for about $30 \%$ of these emissions [4]. The International Energy Agency predicts that the global energy demand will increase by more than $50 \%$ by 2030 if policies remain unchanged and more than $60 \%$ of this increase belongs to the developing countries. This will lead to a $52 \%$ increase in emissions of carbon dioxide $\left(\mathrm{CO}_{2}\right)$, the main greenhouse gas [5].

With the growth in innovative construction methods, it has become imperative that design tools and new industrialized building components, to be provided, can give insights into the sustainability of a building at the design and construction stages, and help the project team to incorporate the notion of constructability with green building principles.

Hence, this paper aims at evaluating the efficiency of various types of prefabricated wall components with regard to resource consumption and environmental impact and consequently, draws an analogy between them and the conventional type.

\section{LITERATURE REVIEW}

Buildings have an enormous and continuously increasing impact on the environment, using about $40 \%$ of natural resources extracted in industrialized countries [6], consuming nearly $70 \%$ of electricity and $12 \%$ of potable water [7], and producing between 45 and $65 \%$ of the waste disposed in landfills [8]. Moreover, they are responsible for a large amount of harmful emissions, accounting for $30 \%$ of greenhouse gases, due to their operation, and an additional $18 \%$ caused indirectly by material exploitation and transportation [9]. At the same time, the bad quality of indoor environments may cause health problems to employees in office buildings, thus, decreasing productivity [10].

In order to mitigate the impact of buildings along their life cycle, green building (GB) has emerged as a new building philosophy, encouraging the use of more environmentally friendly materials, the implementation of techniques to save resources and reduce waste consumption, and improvement of indoor environmental quality, among others [11]. This would result in environmental, financial, economic, and social benefits.

In line with the growing global trend in applying sustainability, Malaysia introduced its national sustainability assessment tool in 2010. Green building index (GBI) is Malaysia's industry recognized green rating tool for buildings to promote sustainability in the built environment. It is specifically developed for tropical climate, environmental and developmental context [12]. The major objectives of GBI include Energy Efficiency, indoor environmental quality, sustainable site planning and 
management, material and resources, water efficiency and innovation in which energy efficiency along with material and resources comprise $32 \%$ of total marks in residential buildings in scale of 100 . This shows the significance of modifying the conventional building construction and use of better materials to enhance the efficiency in the building envelope.

To cope with these challenges, Malaysian construction industry has been called for incorporating innovative construction technique and to switch from traditional to modern techniques like industrialized building system (IBS). IBS is defined as a construction technique in which components are manufactured in a controlled environment (on or offsite), transported, positioned and assembled in a jobsite with minimal additional site works [13]. It is claimed that IBS has a potential usage to promote sustainability from the controlled production environment, minimize waste generation, usage of energy efficient building materials and promote effective logistics [2].

In Malaysia, [13] has classified IBS into five categories, which are steel formwork systems, steel frame system, timber frame system, block work system and pre-cast concrete framing panel and box system.

\section{A. Steel Formwork System}

This system is categorized as an IBS because the process of construction is carried out using a systematic and mechanized method that is by using reusable steel formwork panels. The system allows the rapid on-site placement of cast in situ concrete to form beams, columns, slabs and walls.

\section{B. Steel-Framed Building and Roof Trusses}

According to [14] Steel is a strong and stiff material that is suitable for the construction of frame building. It offers detailing flexibility to architects due to providing long-spanning structure. It is normally used for multi story frames, tall and slander buildings and also for roof construction. The advantages of using steel frame system are high constructability and simplicity of construction as well as greater construction speed.

\section{Prefabricated Timber Framing System}

The prefabricated timber framing system is normally used in the conventional roof truss and timber frames. The timber is prefabricated by joining the members of the truss and using steel plate.

\section{Block Work System}

As [14] pointed out in his paper, this system depends on modular dimension at the design stage, which is identical to Lego blocks to some extent. Furthermore, it applies to load bearing walls by incorporating the columns and the beams as integral part of the walls for all house types. The elements of block work system include interlocking concrete masonry units and lightweight concrete blocks. They are fabricated and cured in the factory.

Precast Concrete Systems here is defined as any precast components that are used in construction industry.

They are categorized as:

1) Precast concrete framing, panel and box systems

2) Precast concrete wall system

\section{3) Building with precast concrete slab}

To limit the scope, this paper studies the impacts of precast concrete walls vis-à-vis conventional masonry walls in terms of resource consumption and environmental impact.

One of the areas that IBS has shown a great merit is the construction of prefabricated wall panels or sandwich panels. Precast, insulated composite wall panels, commonly known as concrete sandwich panels, are typically used for the construction of building envelopes [15].

Such panels consist of two outer layers of concrete separated by a layer of insulation such as polyvinylchloride, polyurethane, polyethylene or polystyrene foams, balsa wood and syntactic foams. [16].

\section{RESEARCH METHODOLOGY}

The case study (Fig. 1) is a double storey bungalow located in Kuala Lumpur. It was modeled in Revit Architecture and exported to Autodesk Ecotect Analysis, which both of them are the epitome of BIM tools, for energy analysis. A conventional $27 \mathrm{~cm}$ brick wall with a layer of cement mortar and granite stone on the exterior surface and a layer of plaster on the interior side of the wall was used as a benchmark. Three types of sandwich panels with two different sizing were selected for the comparison purpose. Then, Monthly space loads and resource consumption in terms of $\mathrm{CO} 2$ production were calculated for each alternative.

TABLE I shows the list of components used and their specifications. It is hypothesized that material used in the external shell has a direct impact on monthly load and carbon emission in the building. It should be noted that these are heating and cooling loads, not energy loads. Obviously for the same space load requirement, we could install a very efficient system or totally inefficient one. The inefficient system, whilst servicing the same space loads, would require a far greater amount of energy than the efficient one.

Other simulation considerations are as follow:

1) The number of occupants was assumed to be four people.

2) The active system for maintaining internal comfort was customized to cover only cooling loads.

3) The thermostat range was set between 18-26 $c^{0}$.

Ecotect provides a range of thermal performance analysis options. At its core is the chartered institute of building services engineers (CIBSE) Admittance Method used to determine internal temperatures and heat loads. This thermal algorithm is very flexible and has no restrictions on building geometry or the number of thermal zones that can be simultaneously analyzed. [19]

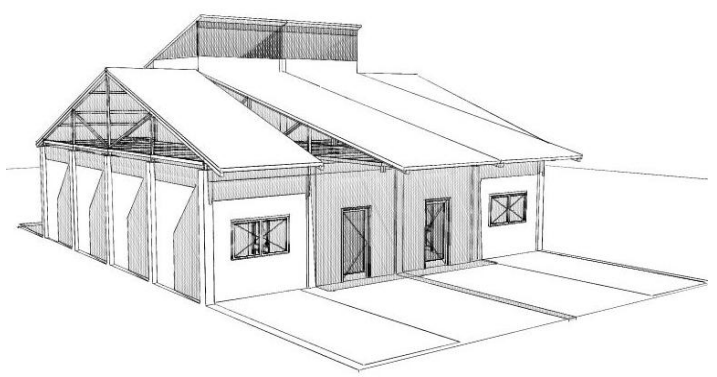

Fig. 1. The double story bungalow 
TABLE I: WALL LAYERS SPECIFICATION S

\begin{tabular}{|c|c|c|c|c|c|}
\hline Type & Layer Name & $\begin{array}{l}\text { Wid h } \\
(\mathrm{mm})\end{array}$ & $\begin{array}{l}\text { Density } \\
\left(\mathrm{Kg} / \mathrm{m}^{3}\right)\end{array}$ & $\begin{array}{l}\text { Specific } \\
\text { Heat } \\
(\mathrm{J} / \mathrm{kgK})\end{array}$ & $\begin{array}{l}\text { Thermal } \\
\text { Conductivity } \\
\text { (W/m.K) }\end{array}$ \\
\hline \multirow[t]{5}{*}{ A-1 } & Paint & 3 & 1250 & 1088 & 0.431 \\
\hline & Concrete & 75 & 950 & 656.9 & 0.209 \\
\hline & Rock Wool & 30 & 200 & 710 & 0.034 \\
\hline & Concrete lightweight & 75 & 950 & 656.9 & 0.209 \\
\hline & Paint & 3 & 1250 & 1088 & 0.431 \\
\hline \multirow[t]{5}{*}{ A-2 } & Paint & 3 & 1250 & 1088 & 0.431 \\
\hline & Concrete lightweight & 100 & 950 & 656.9 & 0.209 \\
\hline & Rock wool & 30 & 200 & 710 & 0.034 \\
\hline & Concrete lightweight & 100 & 950 & 656.9 & 0.209 \\
\hline & Paint & 3 & 1250 & 1088 & 0.431 \\
\hline \multirow[t]{5}{*}{ B-1 } & Paint & 3 & 1250 & 1088 & 0.431 \\
\hline & Concrete lightweight & 75 & 950 & 656.9 & 0.209 \\
\hline & Air gap & 30 & 1.3 & 1004 & 5.56 \\
\hline & Concrete lightweight & 75 & 950 & 656.9 & 0.209 \\
\hline & Paint & 3 & 1250 & 1088 & 0.431 \\
\hline \multirow[t]{5}{*}{ B-2 } & Paint & 3 & 1250 & 1088 & 0.431 \\
\hline & Concrete lightweight & 100 & 950 & 656.9 & 0.209 \\
\hline & Air gap & 30 & 1.3 & 1004 & 5.56 \\
\hline & Concrete lightweight & 100 & 950 & 656.9 & 0.209 \\
\hline & Paint & 3 & 1250 & 1088 & 0.431 \\
\hline \multirow[t]{5}{*}{$\mathrm{C}-1$} & Paint & 3 & 1250 & 1088 & 0.431 \\
\hline & Concrete lightweight & 75 & 950 & 656.9 & 0.209 \\
\hline & Polystyrene foam & 50 & 100 & 1130 & 0.035 \\
\hline & Concrete lightweight & 75 & 950 & 656.9 & 0.209 \\
\hline & Paint & 3 & 1250 & 1088 & 0.431 \\
\hline \multirow[t]{5}{*}{$\mathrm{C}-2$} & Paint & 3 & 1250 & 1088 & 0.431 \\
\hline & Concrete lightweight & 100 & 950 & 656.9 & 0.209 \\
\hline & Polystyrene foam & 50 & 100 & 1130 & 0.035 \\
\hline & Concrete lightweight & 100 & 950 & 656.9 & 0.209 \\
\hline & Paint & 3 & 1250 & 1088 & 0.431 \\
\hline \multirow[t]{4}{*}{ Base } & Granite & 20 & 2650 & 900 & 2.9 \\
\hline & Cement mortar & 10 & 1650 & 920 & 0.72 \\
\hline & Brick masonry & 220 & 2000 & 836.8 & 0.711 \\
\hline & Plaster & 20 & 1250 & 1088 & 0.431 \\
\hline
\end{tabular}

TABLE II: WALL THERMAL PROPERTIES

\begin{tabular}{llllll}
\hline \hline $\begin{array}{l}\text { Wall } \\
\text { Type }\end{array}$ & $\begin{array}{l}\mathrm{U} \text { value } \\
\left(\mathrm{W} / \mathrm{m}^{2} . \mathrm{K}\right)\end{array}$ & $\begin{array}{l}\text { Admittanc } \\
\mathrm{e} \\
\left(\mathrm{W} / \mathrm{m}^{2} . \mathrm{K}\right)\end{array}$ & $\begin{array}{l}\text { Thermal } \\
\text { Decrement } \\
(0-1)\end{array}$ & $\begin{array}{l}\text { Thicknes } \\
\mathrm{s} \\
(\mathrm{mm})\end{array}$ & $\begin{array}{l}\text { Weight } \\
\left(\mathrm{kg} / \mathrm{m}^{3}\right)\end{array}$ \\
\hline Base & 1.8 & 4.36 & 0.31 & 270 & 534.5 \\
A-1 & 0.56 & 2.52 & 0.607 & 186 & 156 \\
A-2 & 0.49 & 2.65 & 0.408 & 236 & 203.5 \\
B-1 & 0.902 & 2.69 & 0.11 & 186 & 150 \\
B-2 & 0.75 & 2.81 & 0.08 & 236 & 197.5 \\
C-1 & 0.43 & 2.59 & 0.64 & 206 & 155 \\
C-2 & 0.39 & 2.7 & 0.44 & 256 & 202.5 \\
\hline \hline
\end{tabular}

\section{ANALYSIS AND DISCUSSION}

Cooling load is the rate at which energy is removed at the cooling coil that serves one or more conditioned spaces in any central air conditioning system [18]. The total building cooling load consists of sensible and latent loads; the former includes the heat transferred through the building envelope such as walls, roof, floor, windows, doors etc and the latter encompasses the heat generated by occupants, equipment, and lights [18]. The sensible load affects the dry bulb temperature, while the latent load affects the moisture content of the conditioned space [19].

Malaysia is a tropical country, hence, ambient temperature doesn't fluctuate wildly, but since the building is more exposed to solar radiation, sensible loads play a major role in heating the internal zones. As a result, to minimize the flow of heat into an air conditioned building, proper measures such as enough insulation for the walls should be provided. Higher thermal conductivity of an insulation material means lower thermal resistance; therefore in order to get an optimum thermal insulation, thicker thickness is required to be used [20].

As thick insulation reduces the space of building significantly, thickness of insulating material is an important criterion in designing building envelope and the calculations should be based on cooling load for energy savings. Thermal transmission in a certain material depends upon the thermal property, in this case the thermal conductivity, and the thickness of that material. The lower the thermal conductivity value, the lower the thermal transmission. Similarly, thicker insulation material results to the lesser thermal transmission [18]. TABLE I shows the layers of the wall types used in this study with their thermal properties. Three types of insulation are used in this case study; $30 \mathrm{~mm}$ of rock wool for the types A-1 and A-2, 30 mm of air gap for the types B-1 and B-2 and $50 \mathrm{~mm}$ of polystyrene foam is used in types $\mathrm{C}-1$ and $\mathrm{C}-2$.

Although the thermal conductivity of rock wool with the value of $0.034 \mathrm{~W} / \mathrm{mK}$ is the lowest compared to the other two types, the polystyrene foam is $20 \mathrm{~mm}$ thicke than the rock wool. Consequently, type C-2 would be the most optimum choice.

It should be noted that Factors such as mass density and specific heat of the materials have influence on another property known as thermal decrement [21].The time it takes for heat wave to propagate surface to the inner surface named as 'time lag' or 'phase lag' and the decreasing ratio of its amplitude during this process is named as 'decrement factor' or 'attenuation factor [22]. More thermal decrement factor would lead to more stabilized internal temperature. As a result, in hot and humid climate, thermal decrement should be higher. Due to the existing variety in thickness, density and specific heat of the wall layers, the impact of thermal decrement on cooling load, in our model, does not follow a regular pattern. Hence, studying the impact of thermal decrement requires further research which is beyond the scope of this paper.

Walls are affected by three heat transfer mechanisms; conduction, convection and radiation. The incoming of solar radiation into the outer wall surface will be converted to heat by absorption and transmitted into the building by conduction. At the same time, convective thermal transmission occurs from air outside of the building to the outer surface of the wall and the inner surface of the wall to the air inside of the building. Since the inside temperature in Malaysia is lower than outside temperature, conduction makes the most portions of heat gains from outside of the wall [23]. This thermal transmission process through the wall can be calculated by the following equation [20].

$q=U\left(T_{i}-T_{o}\right)$

where $q$ is the heat loss in walls, $U$ is the overall heat transfer coefficient which determines heat loss through the building envelope [24]. 
$T_{i}$ is inner temperature, and $T_{o}$ is the mean outer temperature. $q$ Can be determined using the wall conductance $U$ and can be written as follow:

$$
U=\left[R_{i}+R_{w}+R_{i n}+R_{o}\right]^{-1}
$$

where $R_{i}$ and $R_{o}$, are inner and outer surfaces' thermal resistance values. $R_{w}$ is the total thermal resistance of the wall materials without the insulation; $R_{i n}$ is the thermal resistance of the insulation material. So, the thermal resistance of the insulation material may be given as

$$
R_{i n}=\frac{x}{k}
$$

where $x$ and $k$ are the thickness and thermal conductivity of the insulation material, respectively [20]

When all $U$ values obtained through modeling and compared together (TABLE II), it is found that among all the wall types for the tropical climate of our case, wall type C-2 with the least $U$ value in the group is the most suitable in terms of minimum heat transfer rate. This is due to the lower thermal conductivity values and the higher thickness of its layers in comparison with other types. Wall type C-2 is formed of 2 layers of $10 \mathrm{~mm}$ lightweight concrete and a layer of $50 \mathrm{~mm}$ polystyrene foam as an insulator in between. Hence, its thermal conductivity is lower as compared to the other wall types.

\begin{tabular}{|c|c|c|c|c|c|c|c|c|c|c|c|c|}
\hline Type & Jan & Feb & Mar & Apr & May & Jun & Jul & Aug & Sep & Oct & Nov & Dec \\
\hline Base & 2230564 & 2120762 & 2553706 & 2514920 & 2665484 & 2769663 & 2518185 & 2366516 & 2341586 & 2068768 & 2014167 & 1932990 \\
\hline A-1 & 2188370 & 2088340 & 2505502 & 2470625 & 2628178 & 2722658 & 2474876 & 2321476 & 2304449 & 2031807 & 1985776 & 1905212 \\
\hline A-2 & 2058471 & 1966918 & 2371687 & 2337406 & 2493541 & 2577573 & 2334537 & 2190540 & 2177374 & 1910532 & 1869776 & 1790665 \\
\hline B-1 & 2075509 & 1980939 & 2372788 & 2342372 & 2493077 & 2571689 & 2338426 & 2199735 & 2186168 & 1927804 & 1882183 & 1814253 \\
\hline B-2 & 2073022 & 1977863 & 2369572 & 2338854 & 2490176 & 2566857 & 2334271 & 2196722 & 2182682 & 1924114 & 1880669 & 1811996 \\
\hline C-1 & 2077350 & 1983529 & 2392120 & 2357687 & 2515122 & 2600810 & 2356260 & 2209774 & 2196322 & 1926991 & 1885905 & 1805004 \\
\hline $\mathrm{C}-2$ & 2046185 & 1954382 & 2357052 & 2322784 & 2478429 & 2558951 & 2318320 & 2175805 & 2163423 & 1898752 & 1858802 & 1780745 \\
\hline
\end{tabular}

TABLE III: MONTHLY COOLING LOADS (wh)

\begin{tabular}{|c|c|c|c|c|c|c|c|c|c|c|c|c|}
\hline Type & Jan & Feb & Mar & Apr & May & Jun & Jul & Aug & Sep & Oct & Nov & Dec \\
\hline Base & 71253 & 71253 & 81575 & 80337 & 85146 & 88474 & 80441 & 75596. & 747800 & 66085 & 64341 & 61747 \\
\hline A-1 & 69905 & 66710 & 80036 & 78921 & 83954 & 86972 & 79057 & 74157 & 73613 & 64904 & 63433 & 60860 \\
\hline A-2 & 65756 & 62831 & 75761 & 74666 & 79654 & 82338 & 74574 & 69974 & 69554 & 61030 & 59728 & 57201 \\
\hline B-1 & 66300 & 63279 & 75796 & 74825 & 79639 & 82150 & 74699 & 70268 & 69835 & 61582 & 60124 & 57954 \\
\hline B-2 & 66220 & 63181 & 75693 & 74712 & 79546 & 81996 & 74566 & 70172 & 69723 & 61464 & 60076 & 57882 \\
\hline C-1 & 66359 & 63362 & 76414 & 75314 & 80343 & 83080 & 75268 & 70589 & 70159 & 61556 & 60243 & 57659 \\
\hline $\mathrm{C}-2$ & 65363 & 62430 & 75294 & 74199 & 79179 & 81743 & 74056 & 69504 & 69108 & 60654 & 59378 & 56884 \\
\hline
\end{tabular}

TABLE IV: MONTHLY CARBON PRODUCTION (kg)

\section{RESUlts}

TABLES III and IV show the monthly and TABLE V shows the annual cooling loads and Carbon production required to maintain the comfort level of the house according to each wall type used. The annual carbon given is the equivalent amount of cooling load in terms of $\mathrm{Co} 2(\mathrm{~kg})$ production. Fig. 2 and Fig. 3. Show that the selected prefabricated walls, in terms of reducing the cooling loads, perform better than the conventional wall. Among the six types of tested walls, Type C-2 with 25913630 wh cooling load and reduction of $7.7 \%$ in comparison with the base model, is the most optimum and type A-1 with the cooling load of 27627269 wh and $1.6 \%$ decrease, is the least optimum choice compared to others. After that, A2, B2, B1 with $7.1 \%, 6.9 \%$ and $6.8 \%$ respectively stand in the second to the fourth place. The same trend applies to the amount of carbon production.

TABLE V: ANNUAL COOLING LOADS AND CARBON PRODUCTION

\begin{tabular}{lll}
\hline \hline Types & $\begin{array}{l}\text { Annual Cooling } \\
\text { Load }(\mathrm{Wh})\end{array}$ & $\begin{array}{l}\text { Annual } \\
(\mathrm{kg})\end{array}$ \\
\hline & & \\
Base & 28097312 & 897540.645 \\
A-1 & 27627269 & 882524.184 \\
A-2 & 26079020 & 833066.825 \\
B-1 & 26184943 & 836450.655 \\
B-2 & 26146798 & 835232.159 \\
C-1 & 26306874 & 840345.514 \\
C-2 & 25913630 & 827783.825 \\
\hline \hline
\end{tabular}

According to TABLE II, the base wall has the highest U-value which contributes to its significant impact on raising the cooling load and consequently, more carbon emission. Masonry wall is lacking the insulation layer. The lack of insulation allows the outside heat to flow more into the interior environment. Although by increasing the thickness of the wall, the increase in the cooling load can be compensated, but it will have a bad effect on the weight of the structure. Hence, using lighter IBS wall panel is more favorable.

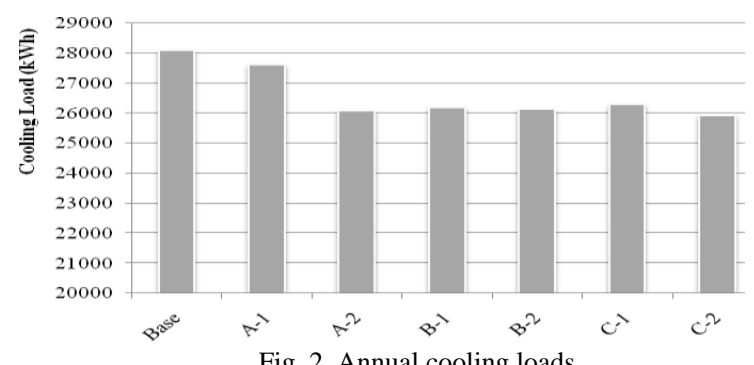

Fig. 2. Annual cooling loads

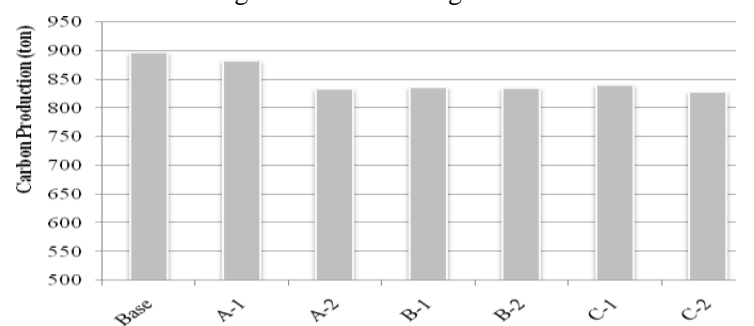

Fig. 3. Annual carbon production 


\section{CONCLUSION}

Designing a building entails considering a plethora of factors. In this competitive market, being able to make quick decisions and choosing the best option is considered as an advantage. With respect to project appraisal and the impact of sustainable criteria such as occupant comfort, heating and cooling loads of the building and carbon emission on the design, BIM can aid the design team to collect the vital information from the model to analyze and select the most beneficial alternative in the early stages of the design.

TABLE VI: U VALUES AND COOLING LOADS DIFFERENCES BETWEEN BASE WALL MODEL AND IBS WALL PANELS

\begin{tabular}{lll}
\hline \hline Types & $\begin{array}{l}\text { Difference in U-value } \\
\text { estimations Compared to } \\
\text { Base Model (W/m2K) }\end{array}$ & $\begin{array}{l}\text { Difference in Cooling } \\
\text { Load estimations } \\
\text { Compared to Base } \\
\text { Model (Wh) }\end{array}$ \\
\hline A-1 & -1.24 & -470043 \\
A-2 & -1.31 & -2018292 \\
B-1 & -0.898 & -1912369 \\
B-2 & -1.05 & -1950514 \\
C-1 & -1.37 & -1790438 \\
C-2 & -1.41 & -2183682 \\
\hline \hline
\end{tabular}

Regardless of slight reduction in cooling loads by applying prefabricated panels to the exterior envelope of the building vis-à-vis conventional masonry walls (fig. 2, fig. 3, TABLE $\mathrm{VI}$ ), it is observed that the IBS practice has no notable impact on saving energy and reducing $\mathrm{CO}_{2}$ footprint. In general, this conclusion is drawn that IBS technology doesn't play a conspicuous role in energy efficiency. However, its contribution to promote sustainability may fall in other categories.

\section{REFERENCES}

[1] A. Haapio and P. Viitaniemi, "A critical review of building environmental assessment tools," environmental impact assessment review, vol. 28, pp. 469-482, Feb 2008.

[2] K. A. Mohamad Kamar, Z. A. Hamid, M. K.Ghani, C. Egbu, and M. Arif, " Collaboration imitative on green construction and sustainability through industrialized building system (IBS) in the Malaysian construction industry," international journal of sustainable construction engineering and technology, available: http://www.cream.com.my/index.php?option=com_contentandview=a rticleandid $=75 \% 3$ Acollaboration-initiative-on-green-construction-and -sustainabilityandcatid $=43 \% 3$ AfrontpageandItemid $=1$. Last accessed 15 th November 2011.

[3] M. Xiaoping, L. Huimin, and L. Qiming, "A comparison study of mainstream sustainable/green building rating tools in the world," in Proc. 9th International Conference on Management and Service Science, Beijing, 2009, pp. 1-5.

[4] Environment face sheet; energy for sustainable development, European Commission Y. 2006.

[5] N. Andrew and R. Oliver, "Green buildings-a niche becomes mainstream," dutch bank research, 2010.

[6] R. M. Pulselli , E. Simoncini, F. M. Pulselli, and S. Bastianoni, "Energy analysis of building manufacturing, maintenance and use: En-building indices to evaluate housing sustainability," energy and buildings, vol. 39, pp. 620-628, 2007.

[7] W. Wang, R. Zmeureanua, and H. Rivard, "Applying multi-objective genetic algorithms in green building design optimization," building and environment.vol. 40, pp. 1512-1525, 2005.

[8] J. Yudelson, The green building revolution, Washington, D.C.: Island Press.2008, ch. 1, pp. 8.

[9] B. Venkatarama and K. Jagadish, "Embodied energy of common and alternative building materials and technologies," energy and buildings. vol. 35, pp.129-137, 2003.

[10] R. Ries, M. Bilec, N. Gokhan, and K. Needy, "The economic benefits of green buildings: a comprehensive case study," the engineering economist, Vol. 51, pp.259-295, 2006.
[11] C. Thormark, "The effect of material choice on the total energy need and recycling potential of a building," building and environment, vol. 41, pp.1019-1026, 2006.

[12] S. Chua and T. Oha, "Green progress and prospect in Malaysia," renewable and sustainable energy reviews. Vol. 15, pp. 2850-2861, 2011.

[13] IBS Roadmap (2003-2010), construction industry development board (CIDB) Malaysia Y.12-2006

[14] M. H. Sufian,Y. M. Razalli, and A. Z., Fazli, "PKNS engineering and construction berhad (PECB) experiences in industrialised building systems (IBS)," in Proc. MIIE, kuala lumpur, 2009.

[15] G. Lucier, S. Rizkalla, and T. Hassan, "Thermally efficient precast concrete sandwich load bearing wall panels reinforced with cfrp," in Proc. 3rd fib international congress, chicago, 2010.

[16] J. Flanagan, "The realm of building possibilities created by MCM and insulated metal panels," metal construction news, vol. 28, 2007.

[17] Environmental design CIBSE Guide A, chartered institution of building services engineers, London Y.10-1999.

[18] A. Bolatturk, "Optimum insulation thicknesses for building walls with respect to cooling and heating degree-hours in the warmest zone of Turkey," building and environment, vol.43, pp. 1055-1064, 2008.

[19] F. McQuiston and J. Spitler. Cooling and heating load calculation manual, 2nd Ed, USA: ASHRAE (american soc heating refrigeration and air condition engineers), 1997, ch 1.

[20] T. Mahlia, B. Taufiq, Ismail, and H. Masjuki, "Correlation between thermal conductivity and the thickness of selected insulation materials for building wall," energy and buildings, vol. 39, pp. 182-187, 2007.

[21] K. Ulgen, "Experimental and theoretical investigation of effects of walls thermo physical properties on time lag and decrement factor," energy and buildings, vol. 34, pp. 273-278, 2002.

[22] H. Asan and Y, Sancaktar, "Effects of wall's thermo physical properties on time lag and decrement factor," energy and buildings, vol. 28, pp. 159-166, 1998.

[23] M. Tosun and K. Dincer, "Modelling of a thermal insulation system based on the coldest temperature conditions by using artificial neural networks to determine performance of building for wall types in Turkey," international journal of refrigeration, vol. 34, pp. 362-373, 2011.

[24] Gul. K. Oral and Z. Yilmaz, "Building form for cold climatic zones related to building envelope from heating energy conservation point of view," energy and buildings, vol. 35, pp. 383-388, 2003.

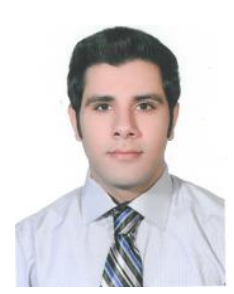

Mahmoud Shakouri Hassanabadi was born in Tehran, Iran in 1985. He received his degree in architecture from Islamic Azad University, Iran in 2007 and started his master degree in construction management at University Teknologi Malaysia in 2010. From 2007 to 2010 he worked as a contract administrator and field engineer in a contracting firm. His practical experience is mostly construction of stadiums and sport complexes. He also worked as an ESL teacher in Kish Institute of Science and Technology in Iran from 2007 to 2010. His research interests are mainly building information modeling, energy analysis and also improving the performance of buildings with regard to sustainability standards. Currently, as a part of his thesis research he is trying to optimize the level of energy consumption in terms of reducing the cooling loads and fabric gains in a state housing project in Malaysia which also complies with Malaysia's new sustainability assessment tool known as Green Building Index.

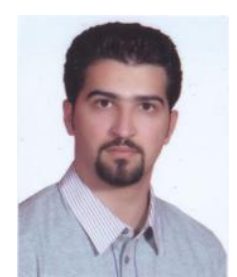

Seyed Saeed Banihashemi was born in Ardabil, Iran in 1985. He received his degree in architecture from Iran in 2008 and started his master degree in construction management at University Teknologi Malaysia in 2010. From 2008 to 2010, he worked as a design studio member and field engineer in a construction firm. His practical experience is mostly in design and project management.

His research interests are mainly building information modeling, industrialized building system, energy analysis and also green building rating tools. Currently, as a part of his thesis research, he is trying to integrate industrialized building system with building information modeling by virtue of developing IFC algorithms for some prefabricated components. 